\title{
Bath Salts, Spice, and Related Designer Drugs: The Science Behind the Headlines
}

\author{
Michael H. Baumann, ${ }^{1}$ Ernesto Solis, Jr., ${ }^{2}$ Lucas R. Watterson, ${ }^{3}$ Julie A. Marusich, ${ }^{4}$ William E. Fantegrossi, ${ }^{5}$ \\ and Jenny L. Wiley ${ }^{4}$ \\ ${ }^{1}$ Designer Drug Research Unit, Intramural Research Program, National Institute on Drug Abuse, National Institutes of Health, Baltimore, Maryland 21224, \\ ${ }^{2}$ Department of Physiology \& Biophysics, Virginia Commonwealth University School of Medicine, Richmond, Virginia 23298, ${ }^{3}$ Department of Psychology, \\ Behavioral Neuroscience Area, Arizona State University, Tempe, Arizona 85287, ${ }^{4}$ RTI International, Research Triangle Park, North Carolina 27709, and \\ ${ }^{5}$ Department of Pharmacology \& Toxicology, University of Arkansas for Medical Sciences, Little Rock, Arkansas 72205
}

The abuse of synthetic psychoactive substances known as "designer drugs," or "new psychoactive substances" (NPS), is increasing at an alarming rate. NPS are purchased as alternatives to traditional illicit drugs of abuse and are manufactured to circumvent laws regulating the sale and use of controlled substances. Synthetic cathinones (i.e., "bath salts") and synthetic cannabinoids (i.e., "spice") are two types of NPS that have received substantial media attention. Although low recreational doses of bath salts or spice compounds can produce desirable effects, high doses or chronic exposure often leads to dangerous medical consequences, including psychosis, violent behaviors, tachycardia, hyperthermia, and even death. Despite the popularity of NPS, there is a paucity of scientific data about these drugs. Here we provide a brief up-to-date review describing the mechanisms of action and neurobiological effects of synthetic cathinones and cannabinoids.

\section{Introduction}

Over the past few years, there has been an alarming increase in the abuse of synthetic psychoactive substances known as "designer drugs" or "legal highs" (Rosenbaum et al., 2012; Johnson et al., 2013; Nelson et al., 2014). These substances are purchased as alternatives to traditional illicit drugs of abuse and are manufactured to intentionally circumvent the laws regulating the sale and use of controlled substances. Countries of the European Union have adopted the term "new psychoactive substances" (NPS) to denote this category of emerging drugs, and we will use this nomenclature here (Brandt et al., 2014). NPS are synthesized by clandestine chemists who hijack the medical and patent literature to identify compounds targeting specific transporters or receptors implicated in the effects of psychoactive drugs (Collins, 2011; Lewin et al., 2014). Internet sales and marketing have made NPS easily available on a global scale. Synthetic cathinones (i.e., "bath salts") and synthetic cannabinoids (i.e., "spice") are two types of NPS that have received substantial media attention. Synthetic cathinones produce amphetamine- or cocaine-like subjective effects by activating monoamine systems in the brain and periphery (Baumann et al., 2013a; De Felice et al., 2014), whereas synthetic cannabinoids produce marijuana-like effects by activating the endocannabinoid system (Fattore and Fratta, 2011; Wiley et al.,

Received Aug. 4, 2014; revised Sept. 5, 2014; accepted Sept. 8, 2014.

The work was supported in part by the Intramural Research Program of the National Institute on Drug Abuse, National Institutes of Health.

The authors declare no competing financial interests.

Correspondence should be addressed to Dr. Michael H. Baumann, Designer Drug Research Unit, Intramural Research Program, National Institute on Drug Abuse, National Institutes of Health, Department of Health and Human Services, 333 Cassell Drive, Suite 4400, Baltimore, MD 21224. E-mail: mbaumann@mail.nih.gov.

DOI:10.1523/JNEUROSCI.3223-14.2014

Copyright $\odot 2014$ the authors $\quad 0270-6474 / 14 / 3415150-09 \$ 15.00 / 0$ 2014a). Low recreational doses of bath salts or spice compounds produce the expected desirable effects, but high doses or chronic exposure can lead to dangerous medical consequences, including psychosis, violent behaviors, tachycardia, hyperthermia, and even death (Prosser and Nelson, 2012; Hermanns-Clausen et al., 2013; Kronstrand et al., 2013).

Because of the public health risks posed by NPS, the governments of many countries, including the United States, have passed legislation to ban the sale, possession, and use of specific synthetic cathinones and cannabinoids (Drug Enforcement Administration, 2011, 2013; German et al., 2014). Unfortunately, such legislation has fostered the emergence of new "replacement" analogs that are manufactured to skirt regulatory control, and this trend is expected to continue (Shanks et al., 2012; Seely et al., 2013). Very little information is available regarding the mechanisms of action, pharmacological effects, and toxicological profile for most NPS. The present brief review is based upon the minisymposium, "Bath Salts, Spice and Related Designer Drugs: The Science Behind the Headlines," presented at the Society for Neuroscience annual meeting held in Washington, DC in 2014. Here we aim to provide the most up-to-date information about the pharmacology of synthetic cathinones and cannabinoids, with a specific focus on the neurobiology of these agents.

\footnotetext{
"Bath salts" cathinones interact with monoamine transporters

Psychoactive "bath salts" first appeared in the recreational drug marketplace of the United States during late 2010. By early 2011, there was a dramatic spike in reports of bath salts overdose to poison control centers and an influx of patients admitted to emergency departments with toxic exposures (Spiller et al., 2011;
} 
Amphetamine<smiles>CC(N)Cc1ccccc1</smiles>

Methamphetamine<smiles>CNC(C)Cc1ccccc1</smiles>

Cathinone<smiles>CC(N)C(=O)c1ccccc1</smiles>

Methcathinone<smiles>CNC(C)C(=O)c1ccccc1</smiles>
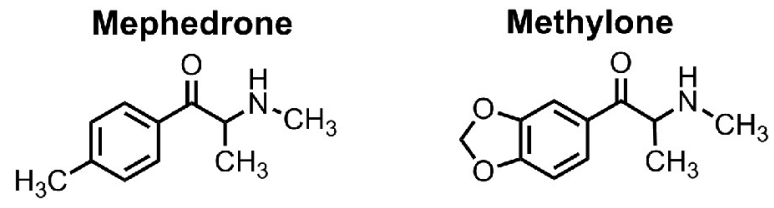

Figure 1. Chemical structures of synthetic cathinones found in bath salts NPS and their relationship to the plant-derived compound cathinone.

Ross et al., 2012). Patients intoxicated with bath salts can display severe symptoms, including psychosis, hallucinations, agitation, tachycardia, hypertension, and hyperthermia, often accompanied by combative or violent behaviors. Forensic analysis of bath salts products revealed the presence of three main synthetic cathinones, depicted in Figure 1: 4-methyl- $N$-methylcathinone (mephedrone),

3 , 4-methylenedioxy- $N$-methylcathinone (methylone), and 3,4methylenedioxypyrovalerone (MDPV) (Spiller et al., 2011; Shanks et al., 2012). These compounds are structurally related to the parent compound cathinone, which is a naturally occurring $\beta$-keto amphetamine with known psychostimulant properties (Schechter and Glennon, 1985; Kalix and Glennon, 1986). Some bath salts powders consist of relatively pure preparations of one synthetic cathinone, but others contain mixtures of two or more different cathinones, along with adulterants, including caffeine, lidocaine, or piperazines (Davies et al., 2010; Zawilska and Wojcieszak, 2013). Like other stimulant drugs, synthetic cathinones target monoamine transporters expressed on nerve cells and other cell types (Hadlock et al., 2011; López-Arnau et al., 2012; Martínez-Clemente et al., 2012). Monoamine transporters are members of the SLC6 solute carrier family of proteins that mediate the sodium-dependent uptake of monoamine neurotransmitters, and there are specific transporters for norepinephrine (NET), dopamine (DAT), and 5-HT (SERT) (Kristensen et al., 2011). Drugs that interact with transporters can be divided into two types: (1) amphetamine-like substrates or (2) cocaine-like blockers (Rothman and Baumann, 2003; Sitte and Freissmuth, 2010). Both types of drugs increase extracellular concentrations of monoamines, but substrates induce transporter-mediated inward currents (i.e., depolarization) and transmitter efflux (i.e., release), whereas blockers do not. Additionally, the transporter selectivity for a given drug is predictive of behavioral effects because drugs that are selective for DAT are powerful locomotor stimulants, but drugs selective for SERT are not (Rothman and Baumann, 2006; Howell and Kimmel, 2008).

Several research groups have examined the interaction of synthetic cathinones with monoamine transporters using a variety of methods. In rat brain synaptosomes, mephedrone and methylone are nonselective transporter substrates, thereby evoking the release of preloaded $\left[{ }^{3} \mathrm{H}\right]$ neurotransmitters at DAT, NET, and

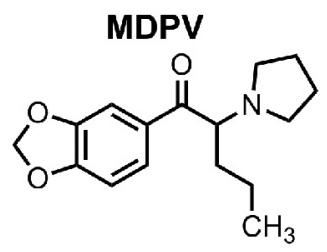

SERT (Baumann et al., 2012). The effects of mephedrone and methylone in synaptosomes mimic those of the illicit drug 3,4-methylenedioxymethamphetamine (MDMA). By contrast, MDPV is a transporter blocker that potently inhibits $\left[{ }^{3} \mathrm{H}\right]$ neurotransmitter uptake at DAT and NET, with little effect at SERT (Baumann et al., 2013b). Importantly, MDPV is 50 and 10 times more potent than cocaine as a blocker at DAT and NET, respectively. Although studies in synaptosomes provide the advantage of high-throughput drug screening in native tissue, experiments in cells allow more detailed assessment of drug-transporter interactions. Assay systems using human transporters expressed in HEK293 cells show that mephedrone, methylone, and other ringsubstituted cathinones are substrates at hDAT, hNET, and hSERT, whereas MDPV is a potent blocker at hDAT and hNET only (Eshleman et al., 2013; Simmler et al., 2013, 2014). Thus, results from human transporters are consistent with results from rat brain synaptosomes. Perhaps the most sophisticated method for examining drug-transporter interactions involves the measurement of transporter-mediated ionic currents using voltage-clamp techniques in cells expressing human transporters (Sonders et al., 1997; Sitte et al., 1998; De Felice et al., 2014). An electrophysiological signature provides definitive information about the mechanism of drug action at the molecular level. Because substrates are translocated through the transporter along with sodium ions, these agents produce transporter-mediated inward currents. Blockers bind to the transporter but are not translocated, so these agents produce outward currents (due to block of an endogenous leak current). As specific examples, amphetamine and mephedrone induce hDAT-mediated inward currents, whereas cocaine and MDPV induce outward currents (Cameron et al., 2013a, b; Kolanos et al., 2013). Together, the data from several lines of evidence agree that ring-substituted cathinones, such as mephedrone and methylone, are nonselective transporter substrates. MDPV is not a transporter substrate, most likely because the drug molecule is too large to fit through the transporter, but acts as a potent blocker at DAT and NET with minimal activity at SERT.

\section{Synthetic cathinones induce stimulant effects in laboratory rodents}

Consistent with their activity as transporter substrates and blockers, synthetic cathinones increase monoamine transmission in laboratory rodents. In vivo microdialysis studies in rats demonstrate that mephedrone and methylone elevate extracellular concentrations of dopamine and 5-HT in the nucleus accumbens, whereas MDPV increases dopamine without affecting 5-HT (Kehr et al., 2011; Baumann et al., 2012, 2013b; Wright et al., 2012). All synthetic cathinones investigated to date produce dose-dependent stimulation of motor activity when administered to rats or mice (Lisek et al., 2012; López-Arnau et al., 2012; Marusich et al., 2012, 2014; Baumann et al., 2013b; Fantegrossi et al., 2013; Gatch et al., 2013), probably due to enhancement of dopamine transmission. Most studies agree that MDPV is $3-10$ times more potent than mephedrone or methylone as a locomotor stimulant. As noted above, bath salts products may contain a 
number of different cathinones, yet MDPV is the chief compound found in blood and urine from fatal cases of bath salts overdose in the United States (Spiller et al., 2011; Murray et al., 2012; Kesha et al., 2013; Wyman et al., 2013). This intriguing observation suggests that MDPV is the chief culprit involved with adverse effects of bath salts. It is tempting to speculate that potent blockade of DAT by MDPV is responsible for neurological symptoms and hyperthermia in bath salts overdose cases, whereas blockade of NET could underlie cardiovascular stimulation. Determining the pharmacokinetics and metabolism of synthetic cathinones in rodent models is essential because clinical data are limited to isolated forensic cases. Mephedrone and methylone are extensively metabolized in the rat (Kamata et al., 2006; LópezArnau et al., 2013; Martínez-Clemente et al., 2013), but the potential bioactivity of various identified metabolites has not been well studied. It is noteworthy that methylone and MDPV possess a 3,4-methylenedioxy ring-substitution akin to the illicit drug MDMA, a compound that displays nonlinear kinetics in rodents and humans (de la Torre et al., 2000; Kolbrich et al., 2008; Baumann et al., 2009; Fantegrossi et al., 2009; Concheiro et al., 2014). The phenomenon of nonlinear kinetics is characterized by greater-than-predicted plasma concentrations of MDMA due to autoinhibition of drug metabolism (Heydari et al., 2004; de la Torre et al., 2004). Similar to MDMA, MDPV is metabolized by $O$-demethylenation, thereby producing the ring-hydroxylated metabolites, 3,4-dihydroxypyrovalerone and 4-hydroxy-3-methoxypyrovalerone (Meyer et al., 2010; Strano-Rossi et al., 2010; Anizan et al., 2014). 3,4-Dihyhdroxypyrovalerone is a potent blocker of DAT and NET (Meltzer et al., 2006), so this metabolite could contribute significantly to the in vivo pharmacology of MDPV. 4-Hydroxy-3-methoxypyrovalerone is a long-lasting metabolite that may prove useful for forensic validation of MDPV exposure in human subjects (Anizan et al., 2014). Whether methylone and MDPV display nonlinear kinetics similar to MDMA is an unresolved issue that warrants investigation. No controlled clinical-laboratory studies with synthetic cathinones have been performed, and such studies are needed to understand the complex pharmacology of these drugs in humans.

\section{Synthetic cathinones have abuse liability in rodent models}

Recently, the addictive potential of synthetic cathinones has been investigated in rodent models. In preclinical abuse liability studies, the intravenous self-administration model is considered the "gold standard" because of its high degree of face and predictive validity (Watterson et al., 2013). From a neurobiological perspective, stimulation of mesolimbic dopamine transmission is a key mechanism underlying drug self-administration behavior (Willuhn et al., 2010; Espana and Jones, 2013). In the selfadministration procedure, rats fitted with indwelling jugular catheters are placed in operant chambers equipped with two levers. Presses on the "active" lever result in a computer-controlled intravenous drug infusion and simultaneous presentation of a stimulus complex (light + tone). Presses on the other lever (i.e., "inactive") produce no consequences but are recorded as a measure of nonspecific behaviors. Comparisons between MDPV and methylone in the self-administration model are of interest because these drugs have structural similarity but differ in their mechanism of action and selectivity for DAT versus SERT (see above). For MDPV, rats readily acquire self-administration across a range of doses (0.05- $0.5 \mathrm{mg} / \mathrm{kg} /$ infusion) (Aarde et al., 2013a; Watterson et al., 2014). Under a progressive ratio schedule of reinforcement, in which the number of lever presses for drug infusion increases exponentially with each successive infusion,
MDPV breakpoints are positively correlated with drug dose (Watterson et al., 2014). Moreover, MDPV breakpoints are similar to those produced by methamphetamine at the same dose $(0.05 \mathrm{mg} / \mathrm{kg} /$ infusion $)$. Escalation of MDPV intake is observed at 0.1 and $0.2 \mathrm{mg} / \mathrm{kg} /$ infusion doses across $6 \mathrm{~h}$ access sessions. This escalation of intake is similar in magnitude to that observed with $0.05 \mathrm{mg} / \mathrm{kg} /$ infusion of methamphetamine and is typically seen with other drugs that support compulsive use in humans (e.g., cocaine and heroin). For methylone, rats display selfadministration across a range of doses $(0.1-0.5 \mathrm{mg} / \mathrm{kg} /$ infusion $)$ (Watterson et al., 2012). As with MDPV, a positive relationship between methylone dose and breakpoints is observed under progressive ratio conditions. However, unlike MDPV, escalation of drug intake is not observed with methylone. These data suggest that the serotonergic effects of methylone may dampen certain reinforcing properties of the drug. Nevertheless, under some conditions, rats will self-administer methylone to the point of convulsions and death, highlighting the dangers of synthetic cathinone use and corroborating reports of methylone-associated deaths in humans (Cawrse et al., 2012; Pearson et al., 2012). Overall, the available evidence shows that MDPV and methylone are readily self-administered by laboratory rats, and these findings agree with reports showing that mephedrone is also self-administered by rats (Hadlock et al., 2011; Aarde et al., 2013b; Motbey et al., 2013). Escalation of drug intake, a cardinal feature of drug addiction, is observed in laboratory rodents self-administering certain synthetic cathinones. Together, these preclinical studies suggest a high abuse potential for synthetic cathinones, such as MDPV, methylone, and mephedrone.

\section{"Spice" cannabinoids interact with the endocannabinoid system}

Plant-derived phytocannabinoids (e.g., $\Delta^{9}$-tetrahydrocannabinol [THC]) and synthetic cannabinoids produce their psychoactive effects through activation of the endocannabinoid system in the brain. This neuromodulatory system is comprised of two identified receptors $\left(\mathrm{CB}_{1}\right.$ in the brain and periphery, and $\mathrm{CB}_{2}$ primarily in the periphery), at least two endogenous ligands (anandamide and 2-arachidonoyl glycerol), and associated synthetic and metabolic enzymes (for review, see Pertwee, 2008). Discovered in the late 1980s and early 1990s (Devane et al., 1988, 1992; Matsuda et al., 1990), the endocannabinoid system contributes to a number of physiological and pathological processes, including appetite, pain, mental illness, reward, and neurodegenerative diseases (Berry and Mechoulam, 2002; Mechoulam et al., 2002; Walker and Huang, 2002; van der Stelt and Di Marzo, 2003; Di Marzo et al., 2004). Development of the first research cannabinoid compounds that would later appear in products confiscated from drug users also occurred during this time span (Huffman et al., 1994; Lainton et al., 1995), although illicit diversion of these compounds did not occur until the early 2000s. The primary goals of the original research were to identify and differentiate structural properties of the newly discovered $\mathrm{CB}_{1}$ and $\mathrm{CB}_{2}$ receptors (Huffman, 2000, 2005; Huffman and Padgett, 2005; Huffman et al., 2005), but the purpose of currently available cannabinoid NPS is to achieve a marijuana-like intoxication. Compared with marijuana, however, abuse of these synthetic substances is associated with a higher prevalence of severe adverse effects, such as hypertension, tachycardia, hallucinations, agitation, seizures, and panic attacks that often require immediate medical care (Seely et al., 2012; Fantegrossi et al., 2014).

The broad structural diversity of cannabinoid agonists was recognized early, as observed in the array of structurally distinct 
THC

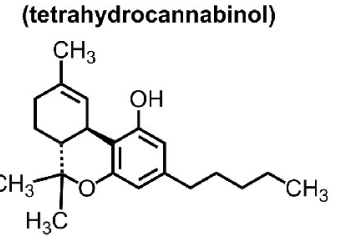

JWH-030 (naphthoylpyrrole)

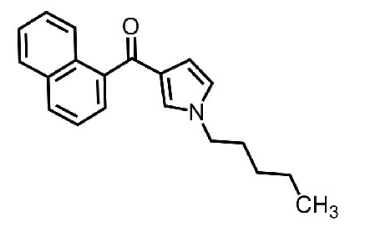

JWH-185

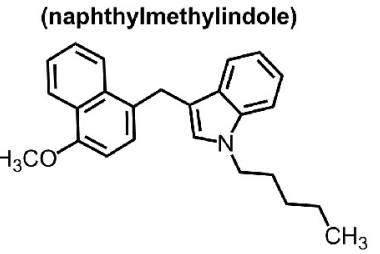

CP47,497 (cyclohexylphenol)

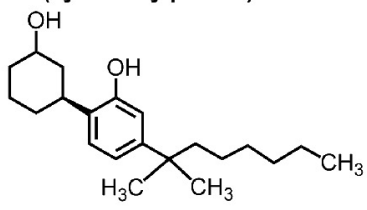

JWH-018 (naphtholyindole)

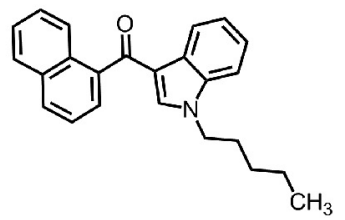

UR-144

(tetramethylcyclopropyl ketone indole)

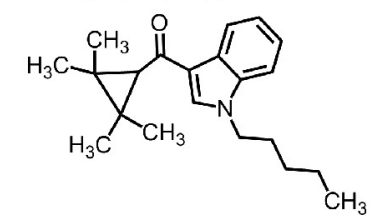

JWH-250

(phenylacetylindole)

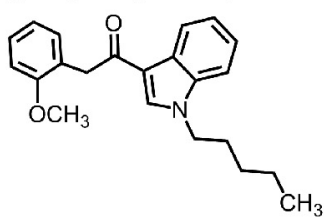

JWH-176

(naphthylmethylindene)

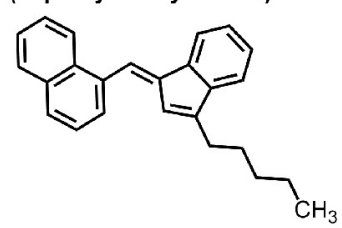

cannabinoid receptors in the brain (Breivogel et al., 2001; Hájos et al., 2001; Monory et al., 2002). These actions may, in turn, modulate in vivo drug effects, leading to unexpected psychoactive effects and peripheral toxicities.

As of 2009, the most prevalent synthetic cannabinoids identified in spice or herbal incense products were classified into seven structural groups, as depicted in Figure 2: naphthoylindoles (e.g., JWH018, JWH-073, AM-2201), naphthylmethylindoles (JWH-185), naphthoylpyrroles (JWH-030), naphthylmethylindenes (JWH176), phenylacetylindoles (JWH-250, RCS-4), cyclohexylphenols (CP47,497), and tetrahydrocannabinols $\left(\Delta^{9}\right.$-THC, HU-210) (European Monitoring Centre for Drugs and Drug Addiction, 2010); however, increased legal restriction has resulted in exploitation of new structural motifs from the scientific literature or led to the invention of new structures. For example, after the United States Drug Enforcement Administration banned JWH-018 and other naphthoylindoles, novel tetramethylcyclopropyl ketone indoles (UR-144, XLR-11) started being identified in con-

Figure 2. Chemical structures of synthetic cannabinoids found in spice NPS and their relationship to the plant-derived compound THC.

classes of compounds that produce cannabinoid activity, including tetrahydrocannabinols, bicyclic cannabinoids, aminoalkylindoles, and anandamide analogs. WIN55212-2, an aminoalkylindole, was the template for synthesis of the original series of indole-derived synthetic cannabinoids (Eissenstat et al., 1995; Wiley et al., 2011). Subsequent studies reported an orderly structure-activity relationship between structural variation in these molecules (e.g., length and branching of the chain) and cannabinoid binding (Huffman et al., 1994; Lainton et al., 1995; Aung et al., 2000) and, when tested, in vivo cannabimimetic activity (Wiley et al., 1998, 2012a, b, 2014a). Interestingly, some of the compounds in this series with the best $\mathrm{CB}_{1}$ receptor affinities are the ones that were identified in earliest "spice" products, demonstrating that clandestine chemists are mining the scientific literature to guide manufacture.

Yet, despite similarity to THC in much of its pharmacology, WIN55212-2 differs from other classes of cannabinoids in its molecular interactions with cannabinoid receptors, having at least one unique site of attachment that is not shared by other cannabinoid agonists or by the $\mathrm{CB}_{1}$ antagonist rimonabant (Petitet et al., 1996; Song and Bonner, 1996). In addition, WIN55212-2 has higher affinity for peripheral cannabinoid $\mathrm{CB}_{2}$ receptors than for $\mathrm{CB}_{1}$ receptors in the brain (Showalter et al., 1996), a property it shares with many of the synthetic cannabinoids that have been identified in confiscated NPS (Huffman and Padgett, 2005; Manera et al., 2008). Because the physiological functions of $\mathrm{CB}_{2}$ receptors are not completely understood, it is possible that agonist action at these receptors may modulate the pharmacological profile of WIN55212-2 and other indoles. In addition, WIN55212-2 and many other indole-derived cannabinoids are full agonists at $\mathrm{CB}_{1}$ receptors, compared with the weak partial agonist activity of THC (Atwood et al., 2011; Brents et al., 2011, 2012; Chimalakonda et al., 2012). Finally, several lines of research have suggested that WIN55212-2 (and perhaps other structurally related synthetic cannabinoids) interacts with non-

fiscated products (Fig. 2). The sheer number of possible combinations of structural constituents is staggering and complicates prediction of which NPS are likely to be included in the next round of "product."

\section{Synthetic cannabinoids display complex pharmacokinetics and metabolism}

In addition to the obvious risk of using compounds with unknown pharmacological properties, synthetic cannabinoids have an additional set of potential risks associated with exposure to pyrolytic byproducts of the compound or the plant material on which it is sprayed (because smoking is the normal route of administration) (Kavanagh et al., 2013), biotransformation to active metabolites, and shared metabolic pathways with commonly used medications, which may lead to drug-drug interactions. Despite the popular use of these substances, little is known about their pharmacokinetics or their in vivo pharmacology and toxicology. The few published pharmacokinetic studies have shown that, like phytocannabinoids, synthetic cannabinoids are highly lipophilic and the parent compounds readily cross the bloodbrain-barrier and are distributed to areas high in $\mathrm{CB}_{1}$ receptor density (Dhawan et al., 2006; Wiebelhaus et al., 2012). Whereas THC has only one major psychoactive Phase I metabolite (11hydroxy-THC) (Huestis et al., 1992), metabolism of synthetic cannabinoids can proceed via several pathways, resulting in multiple metabolites. Earlier studies reported that several Phase I hydroxylated metabolites of AM2201 (Chimalakonda et al., 2012), JWH-018 (Brents et al., 2011), and JWH-073 (Brents et al., 2012) retain high affinity for $\mathrm{CB}_{1}$ receptors, often higher than that of THC. In addition, these metabolites exhibit a range of intrinsic efficacies at the $\mathrm{CB}_{1}$ receptor, from neutral antagonists, to partial agonists, to full agonists. Importantly, in vivo studies demonstrate that these metabolites retain biological effects consistent with their in vitro profiles, in some cases suggesting that they continue to penetrate the brain, or are perhaps generated 
within the brain. In vitro studies using human recombinant $\mathrm{P} 450$ enzymes identified CYP2C9 and CYP1A2 as major isoforms responsible for the generation of these hydroxylated metabolites, which can be detected in human blood and urine as glucuronic acid conjugates (Chimalakonda et al., 2011; Patton et al., 2013). Mechanistic studies have shown that selective inhibitors of CYP2C9 (sulfaphenazole) and CYP1A2 ( $\alpha$-naphthoflavone) block oxidation of JWH-018 and AM2201 in human liver microsomes (Chimalakonda et al., 2013), further demonstrating the importance of these $\mathrm{P} 450$ isoforms in the detoxification of these compounds. The in vitro evidence suggests that individuals with certain allelic variants for these enzymes might be more likely to experience increased toxicity following the use of synthetic cannabinoids. Urinary elimination of synthetic cannabinoids or their metabolites may contribute to the kidney toxicity that has been observed with some of these compounds (Sobolevsky et al., 2010; Moran et al., 2011; Centers for Disease and Prevention, 2013).

Given their shared metabolism via P450 isoforms, combined use of synthetic cannabinoids and various prescription medications may result in adverse drug-drug reactions. Commonly prescribed drugs, such as valproic acid and sertraline potently inhibit CYP2C9, whereas drugs, such as ciprofloxacin and fluvoxamine, strongly inhibit CYP1A2. Additionally, CYP2C9 is a major polymorphic enzyme (Paine et al., 2006) and is responsible for the metabolism of a number of clinically important drugs, such as warfarin, phenytoin, tolbutamide, losartan, and ibuprofen. More than five allelic variants have been identified, including two "loss of function" variants (CYP2C9*4 and CYP2C9*5) (Seng and Seng, 2008). Similarly, CYP1A2 is responsible for the metabolism of numerous psychiatric medications, including olanzapine, clozapine, haloperidol, thioridazine, imipramine, clomipramine, fluvoxamine, and tacrine (Shirley et al., 2003) but is well conserved without common functional polymorphisms (Hiratsuka, 2012). Hence, the possibility of drug-drug interactions is a serious consideration using synthetic cannabinoids.

\section{Synthetic cannabinoids produce THC-like stimulus effects in animal models}

To the extent that synthetic cannabinoids have been evaluated in vivo, they share the capacity of THC to produce a tetrad of diagnostic effects: locomotor suppression, antinociception, hypothermia, and catalepsy (Wiley et al., 2014a). Synthetic cannabinoids also engender THC-like discriminative stimulus effects in rodents and nonhuman primates (Wiley et al., 1995; Wiley et al., 1998). Unlike the situation with synthetic cathinones, a robust model of intravenous THC self-administration in rodents has not been established, although self-administration has been reported in squirrel monkeys (Tanda et al., 2000; Justinova et al., 2003). WIN55212-2 self-administration has been reported in rodents (Fattore et al., 2001; Deiana et al., 2007); however, its usefulness as a screening tool for identification of synthetic cannabinoids likely to be abused has been disputed (Lefever et al., 2014). Consequently, THC discrimination in animal models remains the most pharmacologically selective method for assessing the likelihood that novel compounds will produce marijuana-like subjective effects in humans (Balster and Prescott, 1992). Animals used in drug discrimination learn to associate the interoceptive cues produced by THC or vehicle with one of two responses. For example, to receive food reinforcement, the animal must press a lever on the right side of the test chamber if an injection of THC was given before the session. If a THC injection was not given (e.g., vehicle injection), the animal must respond on the left lever to receive food. After the discrimination is established, other compounds are administered to determine whether they produce interoceptive cues similar to those produced by THC. Early research found that a number of naphthoylindoles, naphthylmethylindoles, and naphthoylpyrroles produce cannabinoid effects in rats or rhesus monkeys trained to discriminate THC or CP55940 from vehicle (Wiley et al., 1995, 1998). Later studies confirmed these results with other naphthoylindoles (JWH-018, JWH-073, and AM5983) (Järbe et al., 2010, 2011, 2014; Ginsburg et al., 2012; Marusich et al., 2013) and extended them to other classes of indole-derived cannabinoids, including phenylacetylindoles (Vann et al., 2009; Järbe et al., 2011) and tetramethylcyclopropyl ketone indoles (UR-144, XLR-11) (Wiley et al., 2013). In studies where more than one compound has been evaluated, the rank order of drug potency parallels $\mathrm{CB}_{1}$ affinity, with compounds showing the highest affinity for $\mathrm{CB}_{1}$ also showing the highest potency in drug discrimination. Reversal by the $\mathrm{CB}_{1}$ antagonist rimonabant provides further verification that $\mathrm{CB}_{1}$ receptors mediate the THC-like discriminative stimulus effects of synthetic cannabinoids (Järbe et al., 2011; Ginsburg et al., 2012). In the context of a THC discrimination procedure, cross-tolerance of THC and synthetic cannabinoids (CP55940, JWH-018, and JWH-073) has also been demonstrated in rhesus monkeys chronically treated with THC (Hruba et al., 2012). More recently, cross-substitution of THC and synthetic cannabinoids has been reported in separate groups of rodents trained to discriminate THC or JWH-018 from vehicle (Wiley et al., 2014b). To the limited extent to which they have been assessed, sex differences in the discriminative stimulus effects of synthetic cannabinoids are not apparent (J.L.W. and J.A.M., unpublished data). Finally, the duration of action of some synthetic cannabinoids in drug discrimination has been reported to be shorter than that of THC (Ginsburg et al., 2012), suggesting that the synthetic drugs may be administered more frequently with resultant enhancement of abuse potential.

\section{Conclusions}

In conclusion, this brief review has summarized the latest scientific data on the neurobiology of synthetic stimulants and cannabinoids. The available information suggests that most of these NPS resemble their progenitors (i.e., stimulants and THC) in their basic pharmacology, but these substances may have unexpected toxicological effects related to factors, such as dosage, efficacy, or active metabolites, which remain largely unexplored because most mechanistic research has focused on the stimulant actions of cathinones and cannabimimetic effects of synthetic cannabinoids. Potential "off-target" sites of action for most NPS are not known. This paucity of scientific knowledge is in direct contrast to the widespread availability of peer-to-peer information and access via the Internet and other electronic media, particularly for adolescents (Wax, 2002; Castellanos et al., 2011). Despite an alarming increase in the number of people seeking medical attention following use of NPS (Spiller et al., 2011; Centers for Disease and Prevention, 2011; Harris and Brown, 2013; Helander et al., 2014), the actual incidence of use is probably still underestimated because tracking continues to be difficult, partially due to inadequacy of detecting most substances. Meanwhile, the number of new "replacement" cathinones and cannabinoids continues to grow. The challenge for scientists, clinicians, and policymakers is to discover creative and effective ways to maximize their efforts in responding to this rapidly changing drug landscape. 


\section{References}

Aarde SM, Huang PK, Creehan KM, Dickerson TJ, Taffe MA (2013a) The novel recreational drug 3,4-methylenedioxypyrovalerone (MDPV) is a potent psychomotor stimulant: self-administration and locomotor activity in rats. Neuropharmacology 71:130-140. CrossRef Medline

Aarde SM, Angrish D, Barlow DJ, Wright MJ Jr, Vandewater SA, Creehan KM, Houseknecht KL, Dickerson TJ, Taffe MA (2013b) Mephedrone (4-methylmethcathinone) supports intravenous self-administration in Sprague-Dawley and Wistar rats. Addict Biol 18:786-799. CrossRef Medline

Anizan S, Ellefsen K, Concheiro M, Suzuki M, Rice KC, Baumann MH, Huestis MA (2014) 3,4-Methylenedioxypyrovalerone (MDPV) and metabolites quantification in human and rat plasma by liquid chromatography-high resolution mass spectrometry. Anal Chim Acta 827:54-63. CrossRef Medline

Atwood BK, Lee D, Straiker A, Widlanski TS, Mackie K (2011) CP47,497-C8 and JWH073, commonly found in 'Spice' herbal blends, are potent and efficacious CB(1) cannabinoid receptor agonists. Eur J Pharmacol 659:139-145. CrossRef Medline

Aung MM, Griffin G, Huffman JW, Wu M, Keel C, Yang B, Showalter VM, Abood ME, Martin BR (2000) Influence of the N-1 alkyl chain length of cannabimimetic indoles upon $\mathrm{CB}(1)$ and $\mathrm{CB}(2)$ receptor binding. Drug Alcohol Depend 60:133-140. CrossRef Medline

Balster RL, Prescott WR (1992) Delta 9-tetrahydrocannabinol discrimination in rats as a model for cannabis intoxication. Neurosci Biobehav Rev 16:55-62. CrossRef Medline

Baumann MH, Zolkowska D, Kim I, Scheidweiler KB, Rothman RB, Huestis MA (2009) Effects of dose and route of administration on pharmacokinetics of $(+$ or -$)$-3,4-methylenedioxymethamphetamine in the rat. Drug Metab Dispos 37:2163-2170. CrossRef Medline

Baumann MH, Ayestas MA Jr, Partilla JS, Sink JR, Shulgin AT, Daley PF, Brandt SD, Rothman RB, Ruoho AE, Cozzi NV (2012) The designer methcathinone analogs, mephedrone and methylone, are substrates for monoamine transporters in brain tissue. Neuropsychopharmacology 37: 1192-1203. CrossRef Medline

Baumann MH, Partilla JS, Lehner KR (2013a) Psychoactive "bath salts": not so soothing. Eur J Pharmacol 698:1-5. CrossRef Medline

Baumann MH, Partilla JS, Lehner KR, Thorndike EB, Hoffman AF, Holy M, Rothman RB, Goldberg SR, Lupica CR, Sitte HH, Brandt SD, Tella SR, Cozzi NV, Schindler CW (2013b) Powerful cocaine-like actions of 3,4methylenedioxypyrovalerone (MDPV), a principal constituent of psychoactive 'bath salts' products. Neuropsychopharmacology 38:552-562. CrossRef Medline

Berry EM, Mechoulam R (2002) Tetrahydrocannabinol and endocannabinoids in feeding and appetite. Pharmacol Ther 95:185-190. CrossRef Medline

Brandt SD, King LA, Evans-Brown M (2014) The new drug phenomenon. Drug Test Anal 6:587-597. CrossRef Medline

Breivogel CS, Griffin G, Di Marzo V, Martin BR (2001) Evidence for a new $G$ protein-coupled cannabinoid receptor in mouse brain. Mol Pharmacol 60:155-163. CrossRef Medline

Brents LK, Reichard EE, Zimmerman SM, Moran JH, Fantegrossi WE, Prather PL (2011) Phase I hydroxylated metabolites of the K2 synthetic cannabinoid JWH-018 retain in vitro and in vivo cannabinoid 1 receptor affinity and activity. PLoS One 6:e21917. CrossRef Medline

Brents LK, Gallus-Zawada A, Radominska-Pandya A, Vasiljevik T, Prisinzano TE, Fantegrossi WE, Moran JH, Prather PL (2012) Monohydroxylated metabolites of the K2 synthetic cannabinoid JWH-073 retain intermediate to high cannabinoid 1 receptor (CB1R) affinity and exhibit neutral antagonist to partial agonist activity. Biochem Pharmacol 83:952-961. CrossRef Medline

Cameron K, Kolanos R, Vekariya R, De Felice L, Glennon RA (2013a) Mephedrone and methylenedioxypyrovalerone (MDPV), major constituents of "bath salts," produce opposite effects at the human dopamine transporter. Psychopharmacology 227:493-499. CrossRef Medline

Cameron KN, Kolanos R, Solis E Jr, Glennon RA, De Felice LJ (2013b) Bath salts components mephedrone and methylenedioxypyrovalerone (MDPV) act synergistically at the human dopamine transporter. $\mathrm{Br} \mathrm{J}$ Pharmacol 168:1750-1757. CrossRef Medline

Castellanos D, Singh S, Thornton G, Avila M, Moreno A (2011) Synthetic cannabinoid use: a case series of adolescents. J Adolesc Health 49:347349. CrossRef Medline

Cawrse BM, Levine B, Jufer RA, Fowler DR, Vorce SP, Dickson AJ, Holler JM
(2012) Distribution of methylone in four postmortem cases. J Anal Toxicol 36:434-439. CrossRef Medline

Centers for Disease Control and Prevention (2011) Emergency department visits after use of a drug sold as "bath salts": Michigan, November 13, 2010-March 31, 2011. MMWR Morb Mortal Wkly Rep 60:624-627.

Centers for Disease Control and Prevention (2013) Acute kidney injury associated with synthetic cannabinoid use: multiple states, 2012. MMWR Morb Mortal Wkly Rep 62:93-98. Medline

Chimalakonda KC, Moran CL, Kennedy PD, Endres GW, Uzieblo A, Dobrowolski PJ, Fifer EK, Lapoint J, Nelson LS, Hoffman RS, James LP, Radominska-Pandya A, Moran JH (2011) Solid-phase extraction and quantitative measurement of omega and omega-1 metabolites of JWH018 and JWH-073 in human urine. Anal Chem 83:6381-6388. CrossRef Medline

Chimalakonda KC, Seely KA, Bratton SM, Brents LK, Moran CL, Endres GW, James LP, Hollenberg PF, Prather PL, Radominska-Pandya A, Moran JH (2012) Cytochrome P450-mediated oxidative metabolism of abused synthetic cannabinoids found in K2/Spice: identification of novel cannabinoid receptor ligands. Drug Metab Dispos 40:2174-2184. CrossRef Medline

Chimalakonda KC, James LP, Radominska-Pandya A, Moran JH (2013) Sulfaphenazole and alpha-naphthoflavone attenuate the metabolism of the synthetic cannabinoids JWH-018 and AM2201 found in K2/spice. Drug Metab Lett 7:34-38. CrossRef Medline

Collins M (2011) Some new psychoactive substances: precursor chemicals and synthesis-driven end-products. Drug Test Anal 3:404-416. CrossRef Medline

Concheiro M, Baumann MH, Scheidweiler KB, Rothman RB, Marrone GF, Huestis MA (2014) Nonlinear pharmacokinetics of (+/-)3,4-methylenedioxymethamphetamine (MDMA) and its pharmacodynamic consequences in the rat. Drug Metab Dispos 42:119-125. CrossRef Medline

Davies S, Wood DM, Smith G, Button J, Ramsey J, Archer R, Holt DW, Dargan PI (2010) Purchasing 'legal highs' on the Internet: is there consistency in what you get? QJM 103:489-493. CrossRef Medline

de la Torre R, Farré M, Ortuño J, Mas M, Brenneisen R, Roset PN, Segura J, Camí J (2000) Non-linear pharmacokinetics of MDMA ('ecstasy') in humans. Br J Clin Pharmacol 49:104-109. CrossRef Medline

de la Torre R, Farré M, Roset PN, Pizarro N, Abanades S, Segura M, Segura J, Camí J (2004) Human pharmacology of MDMA: pharmacokinetics, metabolism, and disposition. Ther Drug Monit 26:137-144. CrossRef Medline

De Felice LJ, Glennon RA, Negus SS (2014) Synthetic cathinones: chemical phylogeny, physiology, and neuropharmacology. Life Sci 97:20-26. CrossRef Medline

Deiana S, Fattore L, Spano MS, Cossu G, Porcu E, Fadda P, Fratta W (2007) Strain and schedule-dependent differences in the acquisition, maintenance and extinction of intravenous cannabinoid self-administration in rats. Neuropharmacology 52:646-654. CrossRef Medline

Devane WA, Dysarz FA 3rd, Johnson MR, Melvin LS, Howlett AC (1988) Determination and characterization of a cannabinoid receptor in rat brain. Mol Pharmacol 34:605-613. Medline

Devane WA, Hanus L, Breuer A, Pertwee RG, Stevenson LA, Griffin G, Gibson D, Mandelbaum A, Etinger A, Mechoulam R (1992) Isolation and structure of a brain constituent that binds to the cannabinoid receptor. Science 258:1946-1949. CrossRef Medline

Dhawan J, Deng H, Gatley SJ, Makriyannis A, Akinfeleye T, Bruneus M, Dimaio AA, Gifford AN (2006) Evaluation of the in vivo receptor occupancy for the behavioral effects of cannabinoids using a radiolabeled cannabinoid receptor agonist, R-[125/131I]AM2233. Synapse 60:93-101. CrossRef Medline

Di Marzo V, Bifulco M, De Petrocellis L (2004) The endocannabinoid system and its therapeutic exploitation. Nat Rev Drug Discov 3:771-784. CrossRef Medline

Drug Enforcement Administration Department of Justice (2011) Schedules of controlled substances: temporary placement of three synthetic cathinones in Schedule I. Final Order. Federal Register 76:65371-65375. Medline

Drug Enforcement Administration Department of Justice (2013) Establishment of drug codes for 26 substances. Final rule. Federal Register 78:664666. Medline

Eissenstat MA, Bell MR, D’Ambra TE, Alexander EJ, Daum SJ, Ackerman JH, Gruett MD, Kumar V, Estep KG, Olefirowicz EM (1995) Aminoalkylin- 
doles: structure-activity relationships of novel cannabinoid mimetics. J Med Chem 38:3094-3105. CrossRef Medline

European Monitoring Centre for Drugs and Drug Addiction (2010) Synthetic cannabinoids and 'Spice'. In: http://www.emcdda.europa.eu/ publications/drug-profiles/synthetic-cannabinoids

Eshleman AJ, Wolfrum KM, Hatfield MG, Johnson RA, Murphy KV, Janowsky A (2013) Substituted methcathinones differ in transporter and receptor interactions. Biochem Pharmacol 85:1803-1815. CrossRef Medline

Espana RA, Jones SR (2013) Presynaptic dopamine modulation by stimulant self-administration. Front Biosci 5:261-276. Medline

Fantegrossi WE, Murai N, Mathúna BO, Pizarro N, de la Torre R (2009) Discriminative stimulus effects of 3,4-methylenedioxymethamphetamine and its enantiomers in mice: pharmacokinetic considerations. J Pharmacol Exp Ther 329:1006-1015. CrossRef Medline

Fantegrossi WE, Gannon BM, Zimmerman SM, Rice KC (2013) In vivo effects of abused 'bath salt' constituent 3,4-methylenedioxypyrovalerone (MDPV) in mice: drug discrimination, thermoregulation, and locomotor activity. Neuropsychopharmacology 38:563-573. CrossRef Medline

Fantegrossi WE, Moran JH, Radominska-Pandya A, Prather PL (2014) Distinct pharmacology and metabolism of K2 synthetic cannabinoids compared to Delta(9)-THC: mechanism underlying greater toxicity? Life Sci 97:45-54. CrossRef Medline

Fattore L, Fratta W (2011) Beyond THC: the new generation of cannabinoid designer drugs. Front Behav Neurosci 5:60. CrossRef Medline

Fattore L, Cossu G, Martellotta CM, Fratta W (2001) Intravenous selfadministration of the cannabinoid CB1 receptor agonist WIN55212-2 in rats. Psychopharmacology 156:410-416. CrossRef Medline

Gatch MB, Taylor CM, Forster MJ (2013) Locomotor stimulant and discriminative stimulus effects of 'bath salt' cathinones. Behav Pharmacol 24:437-447. CrossRef Medline

German CL, Fleckenstein AE, Hanson GR (2014) Bath salts and synthetic cathinones: an emerging designer drug phenomenon. Life Sci 97:2-8. CrossRef Medline

Ginsburg BC, Schulze DR, Hruba L, McMahon LR (2012) JWH-018 and JWH-073: $\delta(9)$-tetrahydrocannabinol-like discriminative stimulus effects in monkeys. J Pharmacol Exp Ther 340:37-45. CrossRef Medline

Hadlock GC, Webb KM, McFadden LM, Chu PW, Ellis JD, Allen SC, Andrenyak DM, Vieira-Brock PL, German CL, Conrad KM, Hoonakker AJ, Gibb JW, Wilkins DG, Hanson GR, Fleckenstein AE (2011) 4-Methylmethcathinone (mephedrone): neuropharmacological effects of a designer stimulant of abuse. J Pharmacol Exp Ther 339:530-536. CrossRef Medline

Hájos N, Ledent C, Freund TF (2001) Novel cannabinoid-sensitive receptor mediates inhibition of glutamatergic synaptic transmission in the hippocampus. Neuroscience 106:1-4. CrossRef Medline

Harris CR, Brown A (2013) Synthetic cannabinoid intoxication: a case series and review. J Emerg Med 44:360-366. CrossRef Medline

Helander A, Backberg M, Hulten P, Al-Saffar Y, Beck O (2014) Detection of new psychoactive substance use among emergency room patients: results from the Swedish STRIDA project. Forensic Sci Int 243:C23-C29. CrossRef Medline

Hermanns-Clausen M, Kneisel S, Szabo B, Auwärter V (2013) Acute toxicity due to the confirmed consumption of synthetic cannabinoids: clinical and laboratory findings. Addiction 108:534-544. CrossRef Medline

Heydari A, Yeo KR, Lennard MS, Ellis SW, Tucker GT, Rostami-Hodjegan A (2004) Mechanism-based inactivation of CYP2D6 by methylenedioxymethamphetamine. Drug Metab Dispos 32:1213-1217. CrossRef Medline

Hiratsuka M (2012) In vitro assessment of the allelic variants of cytochrome P450. Drug Metab Pharmacokinet 27:68-84. CrossRef Medline

Howell LL, Kimmel HL (2008) Monoamine transporters and psychostimulant addiction. Biochem Pharmacol 75:196-217. CrossRef Medline

Hruba L, Ginsburg BC, McMahon LR (2012) Apparent inverse relationship between cannabinoid agonist efficacy and tolerance/cross-tolerance produced by $\Delta(9)$-tetrahydrocannabinol treatment in rhesus monkeys. J Pharmacol Exp Ther 342:843-849. CrossRef Medline

Huestis MA, Henningfield JE, Cone EJ (1992) Blood cannabinoids: I. Absorption of THC and formation of 11-OH-THC and THCCOOH during and after smoking marijuana. J Anal Toxicol 16:276-282. CrossRef Medline
Huffman JW (2000) The search for selective ligands for the CB2 receptor. Curr Pharm Design 6:1323-1337. CrossRef Medline

Huffman JW (2005) CB2 receptor ligands. Mini Rev Med Chem 5:641-649. CrossRef Medline

Huffman JW, Padgett LW (2005) Recent developments in the medicinal chemistry of cannabimimetic indoles, pyrroles and indenes. Curr Med Chem 12:1395-1411. CrossRef Medline

Huffman JW, Dai D, Martin BR, Compton DR (1994) Design, synthesis and pharmacology of cannabimimetic indoles. Bioorg Med Chem Lett 4:563566. CrossRef

Huffman JW, Zengin G, Wu MJ, Lu J, Hynd G, Bushell K, Thompson AL, Bushell S, Tartal C, Hurst DP, Reggio PH, Selley DE, Cassidy MP, Wiley JL, Martin BR (2005) Structure-activity relationships for 1-alkyl-3-(1naphthoyl)indoles at the cannabinoid $\mathrm{CB}(1)$ and $\mathrm{CB}(2)$ receptors: steric and electronic effects of naphthoyl substituents. New highly selective $\mathrm{CB}(2)$ receptor agonists. Bioorg Med Chem 13:89-112. CrossRef Medline

Järbe TU, Li C, Vadivel SK, Makriyannis A (2010) Discriminative stimulus functions of methanandamide and $\Delta(9)$-THC in rats: tests with aminoalkylindoles (WIN55212-2 and AM678) and ethanol. Psychopharmacology 208:87-98. CrossRef Medline

Järbe TU, Deng H, Vadivel SK, Makriyannis A (2011) Cannabinergic aminoalkylindoles, including AM678=JWH018 found in 'Spice', examined using drug $(\Delta(9)$-tetrahydrocannabinol) discrimination for rats. Behav Pharmacol 22:498-507. CrossRef Medline

Järbe TU, LeMay BJ, Halikhedkar A, Wood J, Vadivel SK, Zvonok A, Makriyannis A (2014) Differentiation between low- and high-efficacy CB1 receptor agonists using a drug discrimination protocol for rats. Psychopharmacology 231:489-500. CrossRef Medline

Johnson LA, Johnson RL, Portier RB (2013) Current "legal highs." J Emerg Med 44:1108-1115. CrossRef Medline

Justinova Z, Tanda G, Redhi GH, Goldberg SR (2003) Self-administration of $\Delta 9$-tetrahydrocannabinol (THC) by drug naive squirrel monkeys. Psychopharmacology 169:135-140. CrossRef Medline

Kalix P, Glennon RA (1986) Further evidence for an amphetamine-like mechanism of action of the alkaloid cathinone. Biochem pharmacol 35: 3015-3019. CrossRef Medline

Kamata HT, Shima N, Zaitsu K, Kamata T, Miki A, Nishikawa M, Katagi M, Tsuchihashi H (2006) Metabolism of the recently encountered designer drug, methylone, in humans and rats. Xenobiotica 36:709-723. CrossRef Medline

Kavanagh P, Grigoryev A, Savchuk S, Mikhura I, Formanovsky A (2013) UR-144 in products sold via the Internet: identification of related compounds and characterization of pyrolysis products. Drug Test Anal 5:683692. CrossRef Medline

Kehr J, Ichinose F, Yoshitake S, Goiny M, Sievertsson T, Nyberg F, Yoshitake T (2011) Mephedrone, compared with MDMA (ecstasy) and amphetamine, rapidly increases both dopamine and 5-HT levels in nucleus accumbens of awake rats. Br J Pharmacol 164:1949-1958. CrossRef Medline

Kesha K, Boggs CL, Ripple MG, Allan CH, Levine B, Jufer-Phipps R, Doyon S, Chi P, Fowler DR (2013) Methylenedioxypyrovalerone ("bath salts"), related death: case report and review of the literature. J Forensic Sci 58: 1654-1659. CrossRef Medline

Kolanos R, Solis E Jr, Sakloth F, De Felice LJ, Glennon RA (2013) "Deconstruction" of the abused synthetic cathinone methylenedioxypyrovalerone (MDPV) and an examination of effects at the human dopamine transporter. ACS Chem Neurosci 4:1524-1529. CrossRef Medline

Kolbrich EA, Goodwin RS, Gorelick DA, Hayes RJ, Stein EA, Huestis MA (2008) Plasma pharmacokinetics of 3,4-methylenedioxymethamphetamine after controlled oral administration to young adults. Ther Drug Monitor 30:320-332. CrossRef Medline

Kristensen AS, Andersen J, Jørgensen TN, Sørensen L, Eriksen J, Loland CJ, Strømgaard K, Gether U (2011) SLC6 neurotransmitter transporters: structure, function, and regulation. Pharmacol Rev 63:585-640. CrossRef Medline

Kronstrand R, Roman M, Andersson M, Eklund A (2013) Toxicological findings of synthetic cannabinoids in recreational users. J Anal Toxicol 37:534-541. CrossRef Medline

Lainton JA, Huffman JW, Martin BR, Compton DR (1995) 1-Alkyl-3-(1naphthoyl)pyrroles: a new cannabinoid class. Tetrahedron Lett 36:14011404. CrossRef

Lefever TW, Marusich JA, Antonazzo KR, Wiley JL (2014) Evaluation of 
WIN55212-2 self-administration in rats as a potential cannabinoid abuse liability model. Pharmacol Biochem Behav 118:30-35. CrossRef Medline

Lewin AH, Seltzman HH, Carroll FI, Mascarella SW, Reddy PA (2014) Emergence and properties of spice and bath salts: a medicinal chemistry perspective. Life Sci 97:9-19. CrossRef Medline

Lisek R, Xu W, Yuvasheva E, Chiu YT, Reitz AB, Liu-Chen LY, Rawls SM (2012) Mephedrone ('bath salt') elicits conditioned place preference and dopamine-sensitive motor activation. Drug Alcohol Depend 126:257262. CrossRef Medline

López-Arnau R, Martínez-Clemente J, Pubill D, Escubedo E, Camarasa J (2012) Comparative neuropharmacology of three psychostimulant cathinone derivatives: butylone, mephedrone and methylone. Br J Pharmacol 167:407-420. CrossRef Medline

López-Arnau R, Martínez-Clemente J, Carbo M, Pubill D, Escubedo E, Camarasa J (2013) An integrated pharmacokinetic and pharmacodynamic study of a new drug of abuse, methylone, a synthetic cathinone sold as "bath salts." Prog Neuropsychopharmacol Biol Psychiatry 45:64-72. CrossRef Medline

Manera C, Tuccinardi T, Martinelli A (2008) Indoles and related compounds as cannabinoid ligands. Mini Rev Med Chem 8:370-387. CrossRef Medline

Martínez-Clemente J, Escubedo E, Pubill D, Camarasa J (2012) Interaction of mephedrone with dopamine and serotonin targets in rats. Eur J Neuropsychopharmacol 22:231-236. CrossRef Medline

Martínez-Clemente J, López-Arnau R, Carbó M, Pubill D, Camarasa J, Escubedo E (2013) Mephedrone pharmacokinetics after intravenous and oral administration in rats: relation to pharmacodynamics. Psychopharmacology 229:295-306. CrossRef Medline

Marusich JA, Grant KR, Blough BE, Wiley JL (2012) Effects of synthetic cathinones contained in "bath salts" on motor behavior and a functional observational battery in mice. Neurotoxicology 33:1305-1313. CrossRef Medline

Marusich JA, Lefever TW, Novak SP, Blough BE, WileyJL (2013) Prediction and prevention of prescription drug abuse: role of preclinical assessment of substance abuse liability. Methods Rep RTI Press 1-14.

Marusich JA, Antonazzo KR, Wiley JL, Blough BE, Partilla JS, Baumann MH (2014) Pharmacology of novel synthetic stimulants structurally related to the "bath salts" constituent 3,4-methylenedioxypyrovalerone (MDPV). Neuropharmacology. Advance online publication. Retrieved Mar. 2, 2014. doi: 10.1016/j.neuropharm.2014.02.016. CrossRef Medline

Matsuda LA, Lolait SJ, Brownstein MJ, Young AC, Bonner TI (1990) Structure of a cannabinoid receptor and functional expression of the cloned cDNA. Nature 346:561-564. CrossRef Medline

Mechoulam R, Spatz M, Shohami E (2002) Endocannabinoids and neuroprotection. Sci STKE 2002:re5. CrossRef Medline

Meltzer PC, Butler D, Deschamps JR, Madras BK (2006) 1-(4-Methylphenyl)-2pyrrolidin-1-yl-pentan-1-one (Pyrovalerone) analogues: a promising class of monoamine uptake inhibitors. J Med Chem 49:1420-1432. CrossRef Medline

Meyer MR, Du P, Schuster F, Maurer HH (2010) Studies on the metabolism of the alpha-pyrrolidinophenone designer drug methylenedioxypyrovalerone (MDPV) in rat and human urine and human liver microsomes using GC-MS and LC-high-resolution MS and its detectability in urine by GC-MS. J Mass Spectrom 45:1426-1442. CrossRef Medline

Monory K, Tzavara ET, Lexime J, Ledent C, Parmentier M, Borsodi A, Hanoune J (2002) Novel, not adenylyl cyclase-coupled cannabinoid binding site in cerebellum of mice. Biochem Biophys Res Commun 292:231-235. CrossRef Medline

Moran CL, Le VH, Chimalakonda KC, Smedley AL, Lackey FD, Owen SN, Kennedy PD, Endres GW, Ciske FL, Kramer JB, Kornilov AM, Bratton LD, Dobrowolski PJ, Wessinger WD, Fantegrossi WE, Prather PL, James LP, Radominska-Pandya A, Moran JH (2011) Quantitative measurement of JWH-018 and JWH-073 metabolites excreted in human urine. Anal Chem 83:4228-4236. CrossRef Medline

Motbey CP, Clemens KJ, Apetz N, Winstock AR, Ramsey J, Li KM, Wyatt N, Callaghan PD, Bowen MT, Cornish JL, McGregor IS (2013) High levels of intravenous mephedrone (4-methylmethcathinone) self-administration in rats: neural consequences and comparison with methamphetamine. J Psychopharmacol 27:823-836. CrossRef Medline

Murray BL, Murphy CM, Beuhler MC (2012) Death following recreational use of designer drug "bath salts" containing 3,4-methylenedioxypyrovalerone (MDPV). J Med Toxicol 8:69-75. CrossRef Medline
Nelson ME, Bryant SM, Aks SE (2014) Emerging drugs of abuse. Emerg Med Clin North Am 32:1-28. CrossRef Medline

Paine MF, Hart HL, Ludington SS, Haining RL, Rettie AE, Zeldin DC (2006) The human intestinal cytochrome P450 "pie." Drug Metab Dispos 34: $880-886$. CrossRef

Patton AL, Seely KA, Chimalakonda KC, Tran JP, Trass M, Miranda A, Fantegrossi WE, Kennedy PD, Dobrowolski P, Radominska-Pandya A, McCain KR, James LP, Endres GW, Moran JH (2013) Targeted metabolomic approach for assessing human synthetic cannabinoid exposure and pharmacology. Anal Chem 85:9390-9399. CrossRef Medline

Pearson JM, Hargraves TL, Hair LS, Massucci CJ, Frazee CC 3rd, Garg U, Pietak BR (2012) Three fatal intoxications due to methylone. J Anal Toxicol 36:444-451. CrossRef Medline

Pertwee RG (2008) Ligands that target cannabinoid receptors in the brain: from THC to anandamide and beyond. Addict Biol 13:147-159. CrossRef Medline

Petitet F, Marin L, Doble A (1996) Biochemical and pharmacological characterization of cannabinoid binding sites using $\left[{ }^{3} \mathrm{H}\right] \mathrm{SR} 141716 \mathrm{~A}$. Neuroreport 7:789-792. CrossRef Medline

Prosser JM, Nelson LS (2012) The toxicology of bath salts: a review of synthetic cathinones. J Med Toxicol 8:33-42. CrossRef Medline

Rosenbaum CD, Carreiro SP, Babu KM (2012) Here today, gone tomorrow, and back again? A review of herbal marijuana alternatives (K2, Spice), synthetic cathinones (bath salts), kratom, Salvia divinorum, methoxetamine, and piperazines. J Med Toxicol 8:15-32. CrossRef Medline

Ross EA, Reisfield GM, Watson MC, Chronister CW, Goldberger BA (2012) Psychoactive "bath salts" intoxication with methylenedioxypyrovalerone. J Med 125:854-858. CrossRef Medline

Rothman RB, Baumann MH (2003) Monoamine transporters and psychostimulant drugs. Eur J Pharmacol 479:23-40. CrossRef Medline

Rothman RB, Baumann MH (2006) Balance between dopamine and serotonin release modulates behavioral effects of amphetamine-type drugs. Ann N Y Acad Sci 1074:245-260. CrossRef Medline

Schechter MD, Glennon RA (1985) Cathinone, cocaine and methamphetamine: similarity of behavioral effects. Pharmacol Biochem Behav 22: 913-916. CrossRef Medline

Seely KA, Lapoint J, Moran JH, Fattore L (2012) Spice drugs are more than harmless herbal blends: a review of the pharmacology and toxicology of synthetic cannabinoids. Prog Neuropsychopharmacol Biol Psychiatry 39: 234-243. CrossRef Medline

Seely KA, Patton AL, Moran CL, Womack ML, Prather PL, Fantegrossi WE, Radominska-Pandya A, Endres GW, Channell KB, Smith NH, McCain KR, James LP, Moran JH (2013) Forensic investigation of K2, Spice, and "bath salt" commercial preparations: a three-year study of new designer drug products containing synthetic cannabinoid, stimulant, and hallucinogenic compounds. Forensic Sci Int 233:416-422. CrossRef Medline

Seng KC, Seng CK (2008) The success of the genome-wide association approach: a brief story of a long struggle. Eur J Hum Genet 16:554-564. CrossRef Medline

Shanks KG, Dahn T, Behonick G, Terrell A (2012) Analysis of first and second generation legal highs for synthetic cannabinoids and synthetic stimulants by ultra-performance liquid chromatography and time of flight mass spectrometry. J Anal Toxicol 36:360-371. CrossRef Medline

Shirley KL, Hon YY, Penzak SR, Lam YW, Spratlin V, Jann MW (2003) Correlation of cytochrome P450 (CYP) 1A2 activity using caffeine phenotyping and olanzapine disposition in healthy volunteers. Neuropsychopharmacology 28:961-966. CrossRef Medline

Showalter VM, Compton DR, Martin BR, Abood ME (1996) Evaluation of binding in a transfected cell line expressing a peripheral cannabinoid receptor (CB2): identification of cannabinoid receptor subtype selective ligands. J Pharmacol Exp Ther 278:989-999. Medline

Simmler LD, Buser TA, Donzelli M, Schramm Y, Dieu LH, Huwyler J, Chaboz S, Hoener MC, Liechti ME (2013) Pharmacological characterization of designer cathinones in vitro. Br J Pharmacol 168:458-470. CrossRef Medline

Simmler LD, Rickli A, Hoener MC, Liechti ME (2014) Monoamine transporter and receptor interaction profiles of a new series of designer cathinones. Neuropharmacology 79:152-160. CrossRef Medline

Sitte HH, Freissmuth M (2010) The reverse operation of $\mathrm{Na}(+) / \mathrm{Cl}(-)$ coupled neurotransmitter transporters: why amphetamines take two to tango. J Neurochem 112:340-355. CrossRef Medline

Sitte HH, Huck S, Reither H, Boehm S, Singer EA, Pifl C (1998) Carrier- 
mediated release, transport rates, and charge transfer induced by amphetamine, tyramine, and dopamine in mammalian cells transfected with the human dopamine transporter. J Neurochem 71:1289-1297. CrossRef Medline

Sobolevsky T, Prasolov I, Rodchenkov G (2010) Detection of JWH-018 metabolites in smoking mixture post-administration urine. Forensic Sci Int 200:141-147. CrossRef Medline

Sonders MS, Zhu SJ, Zahniser NR, Kavanaugh MP, Amara SG (1997) Multiple ionic conductances of the human dopamine transporter: the actions of dopamine and psychostimulants. J Neurosci 17:960-974. Medline

Song ZH, Bonner TI (1996) A lysine residue of the cannabinoid receptor is critical for receptor recognition by several agonists but not WIN55212-2. Mol Pharmacol 49:891-896. Medline

Spiller HA, Ryan ML, Weston RG, Jansen J (2011) Clinical experience with and analytical confirmation of "bath salts" and "legal highs" (synthetic cathinones) in the United States. Clin Toxicol 49:499-505. CrossRef Medline

Strano-Rossi S, Cadwallader AB, de la Torre X, Botrè F (2010) Toxicological determination and in vitro metabolism of the designer drug methylenedioxypyrovalerone (MDPV) by gas chromatography/mass spectrometry and liquid chromatography/quadrupole time-of-flight mass spectrometry. Rapid Commun Mass Spectrom 24:2706-2714. CrossRef Medline

Tanda G, Munzar P, Goldberg SR (2000) Self-administration behavior is maintained by the psychoactive ingredient of marijuana in squirrel monkeys. Nat Neurosci 3:1073-1074. CrossRef Medline

van der Stelt M, Di Marzo V (2003) The endocannabinoid system in the basal ganglia and in the mesolimbic reward system: implications for neurological and psychiatric disorders. Eur J Pharmacol 480:133-150. CrossRef Medline

Vann RE, Warner JA, Bushell K, Huffman JW, Martin BR, Wiley JL (2009) Discriminative stimulus properties of $\Delta 9$-tetrahydrocannabinol (THC) in C57BL/6J mice. Eur J Pharmacol 615:102-107. CrossRef Medline

Walker JM, Huang SM (2002) Endocannabinoids in pain modulation. Prostaglandins Leukot Essent Fatty Acids 66:235-242. CrossRef Medline

Watterson LR, Hood L, Sewalia K, Tomek SE, Yahn S, Johnson CT, Wegner S, Blough BE, Marusich JA, Olive MF (2012) The reinforcing and rewarding effects of methylone, a synthetic cathinone commonly found in "bath salts." J Addict Res Ther Suppl 9:pii.002. CrossRef Medline

Watterson LR, Watterson E, Olive MF (2013) Abuse liability of novel 'legal high' designer stimulants: evidence from animal models. Behav Pharmacol 24:341-355. CrossRef Medline

Watterson LR, Kufahl PR, Nemirovsky NE, Sewalia K, Grabenauer M, Thomas BF, Marusich JA, Wegner S, Olive MF (2014) Potent rewarding and reinforcing effects of the synthetic cathinone 3,4-methylenedioxypyrovalerone (MDPV). Addict Biol 19:165-174. CrossRef Medline

Wax PM (2002) Just a click away: recreational drug Web sites on the Internet. Pediatrics 109:e96. CrossRef Medline
Wiebelhaus JM, Poklis JL, Poklis A, Vann RE, Lichtman AH, Wise LE (2012) Inhalation exposure to smoke from synthetic "marijuana" produces potent cannabimimetic effects in mice. Drug Alcohol Depend 126:316-323. CrossRef Medline

Wiley JL, Huffman JW, Balster RL, Martin BR (1995) Pharmacological specificity of the discriminative stimulus effects of 9-tetrahydrocannabinol in rhesus monkeys. Drug Alcohol Depend 40:81-86. CrossRef Medline

Wiley JL, Compton DR, Dai D, Lainton JA, Phillips M, Huffman JW, Martin BR (1998) Structure-activity relationships of indole- and pyrrolederived cannabinoids. J Pharmacol Exp Ther 285:995-1004. Medline

Wiley JL, Marusich JA, Huffman JW, Balster RL, Thomas BF (2011) Hijacking of basic research: the case of synthetic cannabinoids. Methods Rep RTI Press 2011:pi.17971. CrossRef Medline

Wiley JL, Marusich JA, Martin BR, Huffman JW (2012a) 1-Pentyl-3phenylacetylindoles and JWH-018 share in vivo cannabinoid profiles in mice. Drug Alcohol Depend 123:148-153. CrossRef Medline

Wiley JL, Selley DE, Wang P, Kottani R, Gadthula S, Mahadeven A (2012b) 3 -Substituted pyrazole analogs of the cannabinoid type $1(\mathrm{CB}(1))$ receptor antagonist rimonabant: cannabinoid agonist-like effects in mice via non- $\mathrm{CB}(1)$, non- $\mathrm{CB}(2)$ mechanism. J Pharmacol Exp Ther 340:433-444. CrossRef Medline

Wiley JL, Marusich JA, Lefever TW, Grabenauer M, Moore KN, Thomas BF (2013) Cannabinoids in disguise: $\Delta 9$-tetrahydrocannabinol-like effects of tetramethylcyclopropyl ketone indoles. Neuropharmacology 75:145154. CrossRef Medline

Wiley JL, Marusich JA, Huffman JW (2014a) Moving around the molecule: relationship between chemical structure and in vivo activity of synthetic cannabinoids. Life Sci 97:55-63. CrossRef Medline

Wiley JL, Lefever TW, Cortes RA, Marusich JA (2014b) Cross-substitution of $\Delta$-tetrahydrocannabinol and JWH-018 in drug discrimination in rats. Pharmacol Biochem Behav 124:C123-C128. CrossRef Medline

Willuhn I, Wanat MJ, Clark JJ, Phillips PE (2010) Dopamine signaling in the nucleus accumbens of animals self-administering drugs of abuse. Curr Top Behav Neurosci 3:29-71. CrossRef Medline

Wright MJ Jr, Angrish D, Aarde SM, Barlow DJ, Buczynski MW, Creehan KM, Vandewater SA, Parsons LH, Houseknecht KL, Dickerson TJ, Taffe MA (2012) Effect of ambient temperature on the thermoregulatory and locomotor stimulant effects of 4-methylmethcathinone in Wistar and Sprague-Dawley rats. PLoS One 7:e44652. CrossRef Medline

Wyman JF, Lavins ES, Engelhart D, Armstrong EJ, Snell KD, Boggs PD, Taylor SM, Norris RN, Miller FP (2013) Postmortem tissue distribution of MDPV following lethal intoxication by "bath salts." J Anal Toxicol 37:182-185. CrossRef Medline

Zawilska JB, Wojcieszak J (2013) Designer cathinones: an emerging class of novel recreational drugs. Forensic Sci Int 231:42-53. CrossRef Medline 